\title{
Monitoring the state of cenopopulation of Tulipa riparia Knjasev, Kulikov et Philippov in the Southern Urals
}

Milyausha Sh. Barlybayeva

South Ural State Nature Reserve, Bloretsky district, Revet village, Beloretsky district, with. Roar, Central Estate 453560, Republic of Bashkortostan

Maya M. Ishmuratova ${ }^{1}$

Bashkir State University, Ufa, street Zaki Validi 32, Bashkortostan; Bashkir State Reserve, Bashkortostan

Abstract: The article presents the results of longterm monitoring of Tulipa riparia Knjasev, Kulikov et Philippov coenopopulations from family Liliaceae Juss., growing on the territory of the South Ural reserve. It is shown that the cenopopulation is characterized by significant fluctuations in density, number and vitality of individuals, age spectra, morphometric characteristics depending on weather and climate conditions. The age spectrum of the coenopopulation is normal, right-sided, with a predominance of non-flowering individuals. A stress-protective ontogenetic life strategy has been identified for the territory of the reserve. In terms of apophytism, T. riparia belongs to the group of species that are relatively resistant to anthropogenic impact. Moderate anthropogenic load in the form of haymaking in the areas where the species grows has a positive effect on the population characteristics, vitality of individuals and vitality type of coenopopulation.

Key Words: Liliaceae, population, monitoring, conservation, reserve

\section{INTRODUCTION}

To date, there are three species of the genus Tulipa L. in the flora of the Republic of Bashkortostan (RB) Tulipa biebersteiniana Schult. et Schult. fil., Tulipa patens Agardh ex Schult. et Schult. fil. [Determinant of higher plants..., 1988; Mullabayeva, 2005; Red..., 2011] and Tulipa riparia Knjasev, Kulikov et Philippov [Mukhametshina et al., 2013; Barlybayeva et al., 2019]. Two species of the genus Tulipa grow on the territory of the South Ural state nature reserve: T. biebersteiniana [Flora..., 2008] and T. riparia [Mukhametshina et al., 2014]. Tulipa biebersteiniana and T. patens are rare species of the RB flora [Red..., 2011]. Tulipa riparia

Accepted for publication: 15 April 2020

1E-mail: ishmuratova@mail.ru belongs to the non-morals endemic to the southern Urals [Kulikov, 2005], included in the Red book of the Chelyabinsk region [2017].

Tulipa riparia was described relatively recently and represents a Northern triploid sterile race of the genus T. biebersteiniana s. 1. [Knyazev et al., 2001]. There is not enough information about the biology of $T$. riparia in the literature. The distribution of the species has been studied on the territory of the RB to date, ecological and phytocenotic characteristics are described, population studies are being conducted [Mukhametshina et al., 2013, 2014; Barlybayeva et al., 2019, etc.], methods of in situ and ex situ conservation of the species, including biotechnological ones, are being developed [Barlybayeva et al., 2018; Ishmuratova et al., 2019a].

The most effective conservation of rare species in situ is possible in specially protected natural areas. Longterm monitoring studies of rare plant species conducted by us in the reserves of the RB, they are aimed at assessing the state of cenopopulations (CP), identifying the viability potential and developing protection measures, including outside protected areas [Ishbirdin et al., 2005; Ishmuratova et al., 2019b; Barlybayeva et al., 2018, etc.]. It is shown that the success of species conservation depends on the choice of methods and methods of protection, taking into account the belonging of species to certain ecological groups, types of life strategies, as well as their phytocenotic affinity and the degree of anthropotolerency.

The "PVA-population viability analysis" (PVA) is widely used to predict the state of the population. It is based on the study of a wide range of characteristics of the studied species [Morris et al., 1999; McCarthy et al., 2001; Gross, 2002; Brigham, Schwartz, 2003; Tews, 2004; Jacquemyn et al., 2007]. One of the options is a multi-species PVA [Noon et al., 1999], which allows, based on the analysis of the plant community in which the cenopopulation lives, to talk about the prospects for its development. It has been shown [Löfgren et al., 2000; Brook et al., 2006; Reed et al., 2006] that habitat and ecological and phytocenotic characteristics determine the stability and viability of a population to a greater extent than demographic indicators. It was found [Garcia, 2003] that under certain conditions populations can exist for a long time with a low number and density 
of individuals.

Any population is a biologically integral unit that can exist for a long time in space and time. The sustainable existence of a population depends on a variety of endogenous and exogenous factors, including features of ontogenesis, viability of individuals, population structure, reproduction features, natural-climatic, ecological-cenotic, anthropogenic influences, etc. [Adams et al., 2005; Meyer et al., 2006; Ishmuratova, 2006; Maschinski et al., 2006; Münzbergová, 2011; Mursal, Mehdiyeva, 2018, 2019 etc.]. The ability of a plant population in a particular community to maintain its homeostasis is realized through the polyvariance of individual development and the plasticity of their life and reproductive strategies [Grime, 2001].

The article presents the results of long-term monitoring of the condition of $T$. riparia coenopopulation on the territory of the South Ural state nature reserve.

\section{MATERIAL AND METHODS}

Description of investigated object. Tulipa riparia (genus Tulipa family Liliaceae Juss.) - perennial herbaceous plants. The bulb is single, oblong-ovate, elongated at the apex into a long curved neck, located more or less obliquely, develops long plagiotropic stolons in regenerative individuals [Knyazev et al., 2001; Kutlunina, Belyaev, 2008]. Stem height 20-60 $\mathrm{cm}$; leaves 2-3, pointed, rejected. The flower is single, drooping until opening, with pointed perianth lobes. Perianth petals are usually lilac, yellow at the base on the inside, less often yellow with a purple tan. In the studied cenopopulation (CP), individuals with a pinkpurple coloration of the perianth (Fig. 1).

Tulipa riparia - triploid high sterile tulip, endemic to the basin of the Belaya river (Southern Urals), possibly of hybrid origin $T$. biebersteiniana $\times$ T. patens $[\mathrm{Knyazev}$ et al., 2001]. It differs from $T$. biebersteiniana in the larger sizes of all parts, including flowers and wider stamens. The lilac color of the flowers dominates in the populations: in the Yuryuzan river valley it is $95 \%$, in the valleys of the Sim and Inzer rivers - 50\% (alternating lilac or yellow-colored forms), in the Nugush river valley - $25 \%$, in the Belaya river valley - up to $10 \%$. Unlike $T$. biebersteiniana, it is almost exclusively a meadow species. For T. biebersteiniana, diploid $(2 \mathrm{n}=$ 24) and tetraploid forms are indicated [Bochantseva, 1962; Danelia, 1989; Kroon, Jongerius, 1986]. Tulipa riparia is considered as an allotriploid form of $T$. biebersteiniana [Zonneveld, 2009].

Tulipa riparia from $T$. patens is distinguished by larger flowers, sometimes yellow (not pale lilac) flowers, the development of plagiotropic (creeping) stolons, active vegetative propagation, ecology, high sterility, and triploid number of chromosomes [Knyazev et al., 2001]. Tulipa patens does not vegetatively propagate, it develops only vertical stolons of deepening, which forms the characteristic vertical "pyramids" of the remnants of bulbs of past seasons.

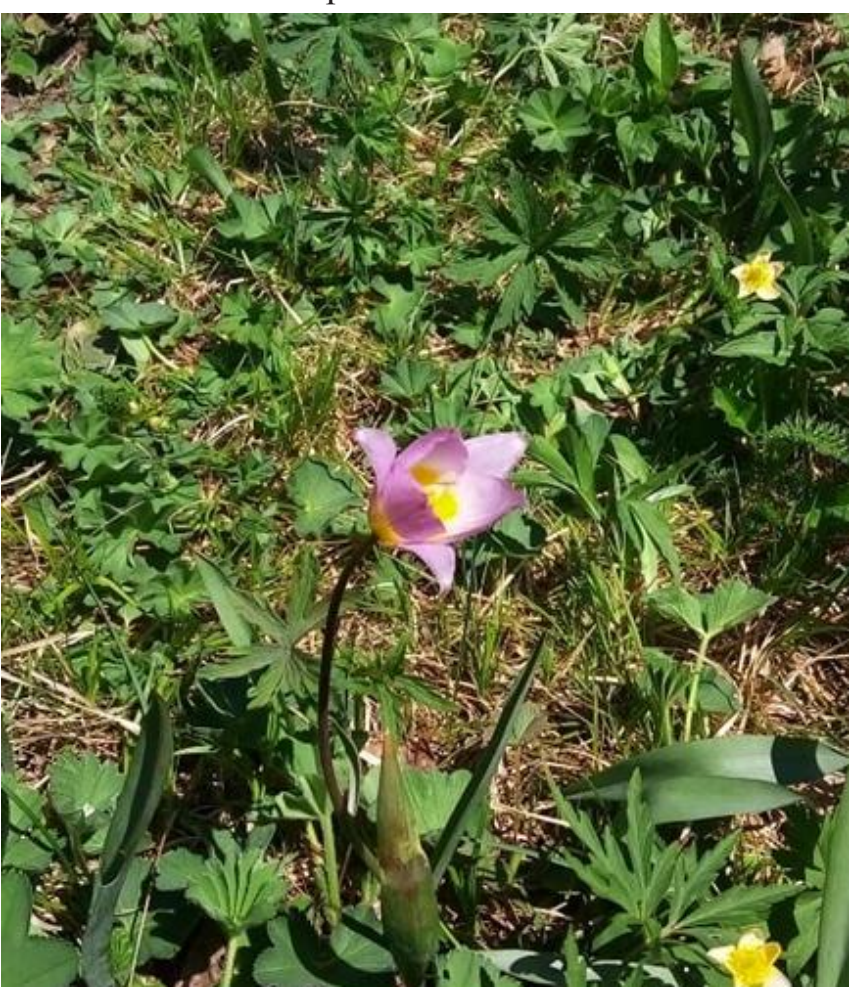

Figure 1. Tulipa riparia in natural habitat.

Ontogenesis of $T$. riparia includes two periods: pregenerative and generative, and 4 age-related states: juvenile, immature, virgininal and generative states [Knyazev et al., 2001]. Is a spring ephemeroid. It grows in floodplain meadows, in bushes and along forest edges in river valleys of the forest zone of the Western slope of the southern Urals, in the basin of the Belaya river (Agidel). In the forest zone and forest-steppe of the PreUrals rarely [Kulikov, 2005; Red book..., 2017].

Description of investigation area. The study was conducted from 2007 to 2018 on the territory of the South Ural state nature reserve (Beloretsky district, Republic of Bashkortostan). The coenopopulations we have stu-died located in the 112 quarter Yamashtinsky forestries, coordinates latitude 54. 192394. longitude 57.613499 (Fig. 2).

The climate of the South Ural reserve is characte-rized by A.I. Kaigorodov [1955] as moderate continental. The 
indicator of continentality is 7 points on the 10-point scale of N.N. Ivanov. In the country's climate zoning schemes, the reserve is located on the South-Eastern edge of the Atlantic-continental forest climate region [Flora and vegetation..., 2008]. The growing season lasts 164 days, including 121 days of active vegetation (from may 11 to September 9). Thermal resources (the sum of temperatures above $10{ }^{\circ} \mathrm{C}$ ) is $1800{ }^{\circ} \mathrm{C}$. Spring and autumn frosts shorten the period of active vegetation to 95-105 days and reduce the thermal resources of the territory. According to thermal conditions, the climate of the reserve is generally characte-rized as moderately cold [Flora..., 2008]. The average annual temperature was determined according to the FSBI "Bashkir UGMS".

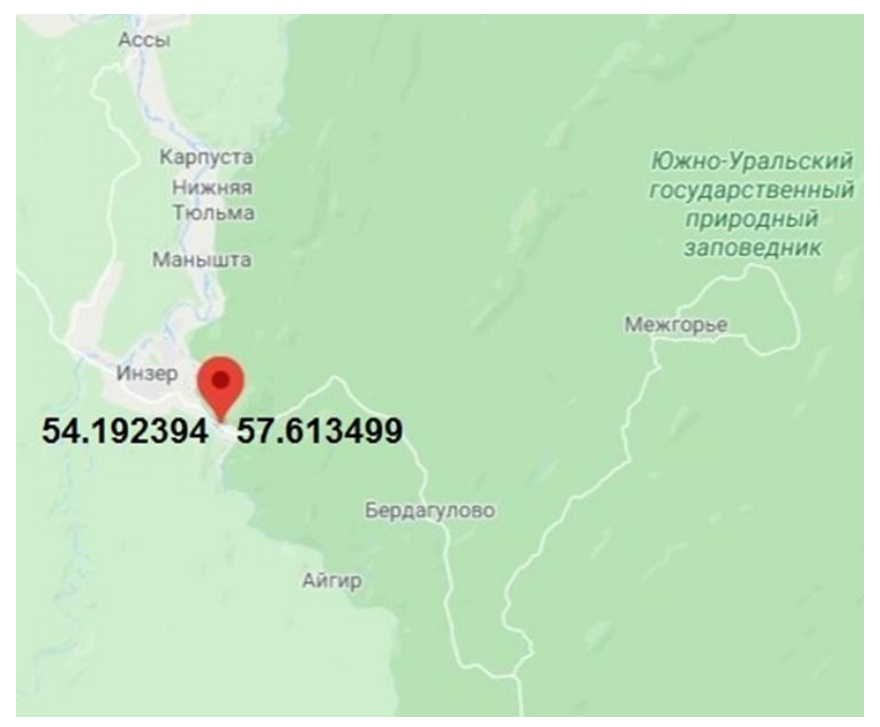

Figure 2. Tulipa riparia CP location map.

Methods of research. Geobotanical descriptions were performed according to the generally accepted method, the description area of $20000 \mathrm{~m}^{2}$, and the abundance of species was taken into account on a nine-point modified Braun-Blanquet scale: $r$ - 1-3 individuals of the plant species on the site; +- up to 10 individuals of the plant species on the site; 1 - up to 100 individuals of a plant species on the site; $2 \mathrm{~m}->>100$ individuals of a plant species on the site; $2 \mathrm{a}-5-12.5 \%$ - projection coverage $5-12.5 \%$;

$2 \mathrm{~b}$ - projective cover, from 12.5 to $25 \%$;

3 - projective cover, from 25 to $50 \%$; 4 - projective cover, from 50 to $75 \%$; 5 - projective cover, from 75 to $100 \%$.

Latin names of plants are given by according to an online flora of all known plants [WFO, 2020].
The assessment of the ecological conditions of CP habitats was carried out on the composition of species in plant communities using the Ellenberg ecological scales [Ellenberg, 1979]. The ecological regime of the habitat was assessed by the following factors: illumination (L), moisture $(\mathrm{Fe})$, temperature $(\mathrm{T})$, richness $(\mathrm{N})$, and soil reaction $(\mathrm{R})$.

Monitoring studies were conducted according to the recommendations of A.R. Ishbirdina et al. [2005] since 2007. Population studies were carried out in accordance with the available methods [Cenopopulation..., 1988]. The unit of account was ramets. The monitoring of the dynamics of the number of individuals was carried out on permanent sites of $1 \mathrm{~m}^{2}$ in size. To take into account the age structure of $\mathrm{CP}$, the following ontogenetic states were distinguished: juvenile (j), immature (im), virgin (v), generative (g).

The following population indices were calculated: 1. recovery index [Glotov, 1998] (Equation 1):

$$
\mathfrak{J} b=j+i m+v /((j+i m+v+g)+(g 1+g 2+g 3)
$$

Equation 1. Calculated as the percentage of pregenerative individuals from the sum of pregenerative and generative individuals. If g1, g2, and g3 States are not distinguished in the complete ontogeny of the species, the share of generative individuals in General is taken into account.

2. index populational optimum [Rabotnov, 1950] (Equation 2):

$$
\text { I p.o. }=(g / \Sigma v+g)
$$

Equation 2. It is calculated as the percentage of generative individuals from the sum of all adult (virgin and generative) individuals.

Evaluation of vitality CP (IVC) carried out on the size spectrum of individuals [Ishbirdin, Ishmuratova, 2004a] (Equation 3):

$$
I V C=\frac{\sum(X i / \overline{X i})}{n}
$$

Equation 3. where $X i$ - average value of the i-th attribute in the coenopopulation, $X i$ - average value of the $i$-th attribute for all coenopopulations (when monitoring a single coenopopulation-the average value for all years of observations), $n$ - number of signs.

To assess the degree of prosperity and depression of coenopopulations, IQ was used [Zlobin, 1989; Ishbirdin et al., 2005] (Equation 4): 


$$
I_{Q}=(a+b) / 2 c
$$

Equation 4, 5. where $a$ - individuals of high vitality, $b$ - individuals of medium vitality, $c$ - objects of low vitality, values $I_{Q}$ greater than 1 will correspond to a prosperous state, less than 1 to depressive, equal to $1-$ equilibrium. If $\mathrm{c}=0$, then the formula has the following form [Vereshchak, Ishmuratova, 2009] (Equation 5):

$$
I_{Q}=(a+b) / 2 c+1
$$

Morphometric analysis of $T$. riparia individuals was carried out on 30 model plants or on all individuals in a generative age state, in the year when the abundance was low (2007). The variability of 9 morphological characters was studied: shoot height $(\mathrm{cm})$, length and width of the first and second leaf $(\mathrm{cm})$, length and width of the outer and inner perianth lobes $(\mathrm{cm})$. The mean value and standard deviation $(\mathrm{M} \pm \mathrm{m})$ and coefficient of variation $(\mathrm{CV}, \%)$ were calculated. Levels of variation of signs are accepted according to G.N. Zaitsev [1984]: $\mathrm{CV}<10 \%$ low, $\mathrm{CV}=11-20 \%$ medium, $\mathrm{CV}>20 \%$ high. The data obtained were processed by variationalstatistical methods using the STATISTICA software package (10.0.228.2).

Ontogenetic strategies of the species were revealed by the nature of changes in the morphological integrity of plants, estimated by the coefficient of determination $\left(R^{2} m\right)$ of morphological characters [Rostova, 2002] in a series of worsening growth conditions [Ishbirdin, Ishmuratova, 2004b]. The gradient of worsening growth conditions was built according to the indicators of the $\mathrm{CP}$ vitality index by the size spectrum of individuals $(I V C)$. High IVC values corresponded to favo-rable growth conditions for individuals; low $I V C$ values corresponded to unfavorable growth conditions.

The species ' resistance to anthropogenic impact was assessed using figure gemerobnost. Gemerobnost species were determined by the composition of species in plant communities, in which each species has an individual spectrum of tolerance to anthropogenic factors [Frank, Klotz, 1990]. We used a modified system Yalasa [Schlueter, 1987; Frank, Klotz, 1990], including the following levels: ahemeroby, oligo -, meso -, eu-, poly -, meta hemeroby. Gemerobnost species includes the following levels:

$a$ - ahemeroby (natuerlich) - types of natural communities, do not tolerate anthropogenic influence; o - oligohemeroby (natunach) - types of communities, close to natural, transferring irregular weak influences; $m$ - mesohemeroby (halbnatuerlich) - types of semi-natural communities, resistant to sporadic anthropogenic influences;

$b$ - $\beta$ - eu hemeroby (naturfern) - types of communities that are far from natural and resistant to intensive use; $c$ - $\alpha$ - eu hemeroby (naturfern) - weed species of natural and anthropogenic communities that suffer regular strong disturbances;

$p$ - poly hemeroby (naturfremd) - specialized weed types of intensive crops;

$t$ - meta hemeroby (kuenstlish) - species of completely disturbed ecosystems that are on the verge of destruction.

$$
A p=\frac{\sum b c p t \text { hemeroby } * 100 \%}{\sum \text { all indicators }}
$$

To assess the stability of a species to anthropogenic impacts calculated the indicator $A p$ - apophiticism [Jakoviak, 1993] (Equation 4), as the share of anthropoto-lerant species in plant communities (species, inclusive in the individual spectrum of hemerobia $b, c, p, t$ components - from growing in heavily used communities found in completely disturbed ecosystems).

An increase in the proportion of anthropotolerant species in plant communities indicates their greater disturbance or greater resistance to these influences, and a decrease, on the contrary, less disturbance and greater vulnerability [Ishmuratova et al., 2003].

\section{RESULTS AND DISCUSSION}

Ecological and phytocenotic characteristics of habitats. On the territory of the South Ural reserve, the studied CP is confined to the floodplain meadow on the right Bank of the Maly Inzer river. The plant community in which $\mathrm{CP}$ grows belongs to the Molinio-Arrhenatheretea class R.Tx. 1937 em. R.Tx. 1970 - these are secondary postforest meadows of the temperate zone of Eurasia, formed on the site of broad-leaved forests on fairly rich unsalted soils. The community consists of the following plants: Achillea millefolium L., Sanguisorba officinalis L., Leucanthemum vulgare Lam., Hypericum perforatum L., Fragaria viridis Weston, Anemone altaica (Fisch. ex C.A.Mey.) Holud, Primula macrocalyx Bunge, Persicaria bistorta (L.) Samp. etc. The projective cover of $T$. riparia in the plant community is $20 \%$.

According to ecological characteristics, T. riparia is a semi-light plant, prefers full light, but can grow in partial shade (Table 1). Tulipa riparia prefers moderate heat (from plains to high-altitude positions), is an 
Table 1. Ecological characteristics of Tulipa riparia habitats in the South Ural nature reserve.

\begin{tabular}{|c|c|c|c|c|}
\hline \multicolumn{5}{|c|}{ Factors } \\
\hline \multirow{2}{*}{$\mathrm{L}$} & \multirow{2}{*}{$\mathrm{T}$} & \multicolumn{3}{|c|}{ soil characteristics } \\
\hline & & $\mathrm{Fe}$ & $\mathrm{R}$ & $\mathrm{N}$ \\
\hline 5.9 & 5.3 & 5.1 & 7.2 & 5.3 \\
\hline
\end{tabular}

indicator of fresh, mostly medium-moist, slightly acidic to slightly alkaline soils. The species prefers moderately rich soils, less often found on poor and highly rich soils. Demographic characteristics of the population. The coenopopulation area of T. riparia is about $20000 \mathrm{~m}^{2}$. During the years of observation, the abundance and density of $T$. riparia individuals in the $\mathrm{CP}$ are relatively high, but significant fluctuations are characteristic of these indicators. The maximum number of generative individuals (361 pcs.) was identified in 2015. In 2013, a relatively low abundance and density of individuals of all age groups was observed. Even such minimal indices of the number of individuals and the incomplete age spectrum allow the CP to stably exist and are not critical for it. In the RB 2007 and 2010 were arid, during these years also recorded a relatively low total number of individuals in the CP. However, the indicators of the total number and the ratio of age groups in the $\mathrm{CP}$ in the dry and other years of the period between droughts (2007, 2009, 2011) did not differ significantly (Fig. 3). Vegetative propagation, which is the only way to self-sustain CP, was not observed in these years. In subsequent years (2014-2018), an increase in the total number and proportion of generative individuals in the age spectrum of the CP was observed. Average annual temperatures did not significantly affect demographic indicators.

In the age spectrum of $T$. riparia, the proportion of juvenile individuals during the observation period was $0-16.3 \%$, percentage of immature individuals $-6.9-57.7 \%$, virgin and generative individuals $24.4-$ $89.4 \%$ and $2.2-50.0 \%$, accordingly (Table 2). The recovery index in the $\mathrm{CP}$ over the years of research is mostly high (above 0.5 ) and varies from year to year, index indicators population optimum $(I$ p.o.) the $\mathrm{CP}$ of T. riparia is low (below 0.5). All this demonstrates maintaining the demographic structure of the CP mainly due to vegetative reproduction.

The breeding method of T. riparia is asexual (vegetative) with deep rejuvenation. Given these features of the species biology, the age spectrum of the studied CP with the absence of seedlings can be described as normal, single-peak (Table 2). In some years, an incomplete age spectrum is observed - juvenile individuals are absent. Basically, adult individuals predominate in $\mathrm{CP}$ - virgin and generative.

The averaged age spectrum of $T$. riparia $\mathrm{CP}$ over the years of monitoring studies is full-membered, righthanded, with a predominance of virginal individuals (p:0; j:3.8; im:13.8; v:64.0; g:18.4) (Fig. 4).

The age spectrum zone of $T$. riparia is relatively narrow for the juvenile age state and wide for the

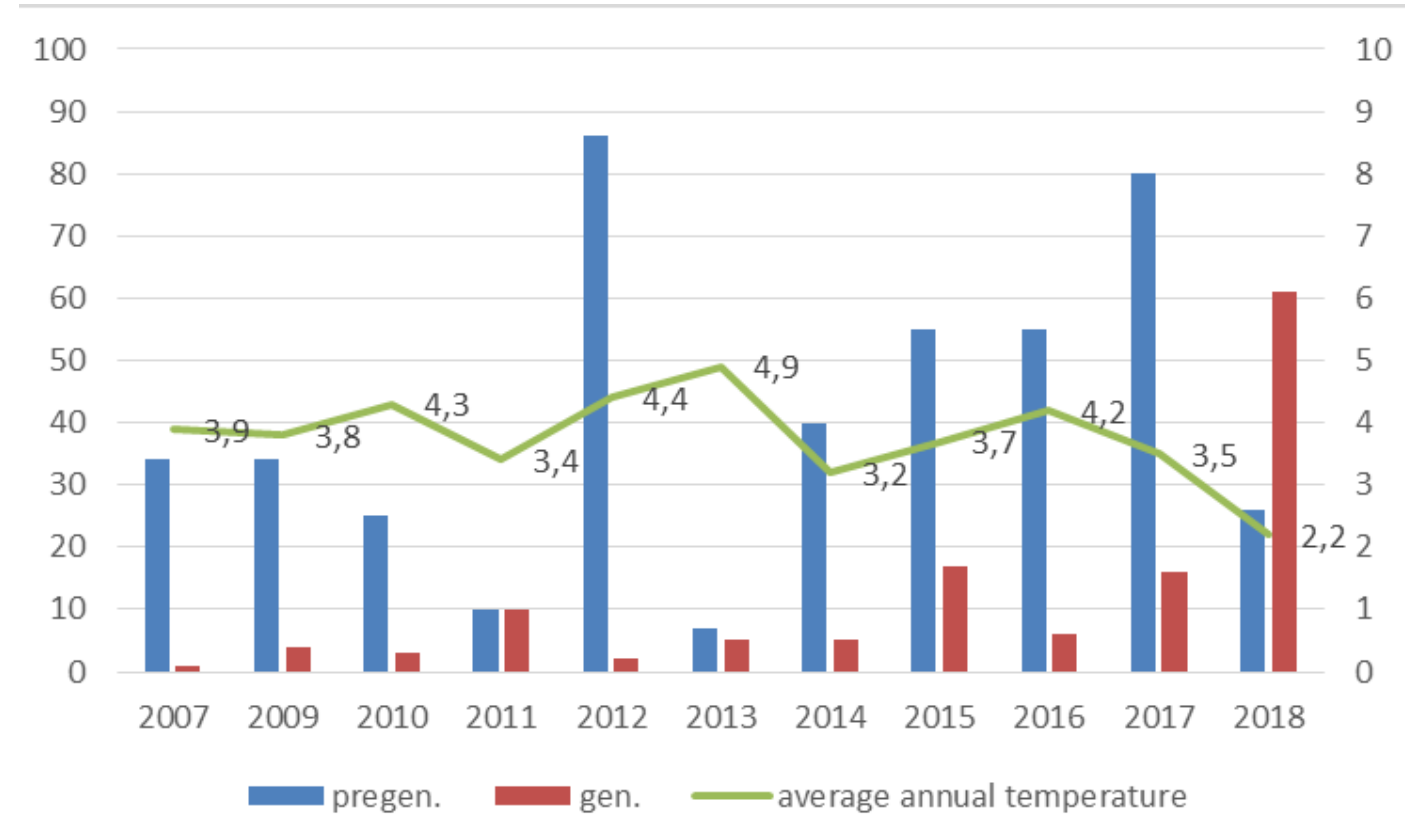

Figure 3. The number of young and generative individuals $\left(\right.$ per $1 \mathrm{~m}^{2}$ ) amid the average annual temperature. 
Table 2. Population characteristics of Tulipa riparia in the South Ural state nature reserve (2007, 2009-2018).

\begin{tabular}{|c|c|c|c|c|c|c|c|c|c|c|}
\hline \multirow{2}{*}{ Year } & \multicolumn{4}{|c|}{$\begin{array}{l}\text { Ontogenetic States on the site } \\
\qquad\left(1 \mathrm{x} 1 \mathrm{~m}^{2}\right), \%\end{array}$} & \multirow{2}{*}{$I V C$} & \multirow{2}{*}{$\begin{array}{c}\text { Density of } \\
\text { pregenera- } \\
\text { tive } \\
\text { individuals } \\
\text { on the area } \\
\left(1 \mathrm{x} 1 \mathrm{~m}^{2}\right), \mathrm{pc} . \\
\end{array}$} & \multirow{2}{*}{$\begin{array}{c}\text { Total } \\
\text { number of } \\
\text { genera-tive } \\
\text { indivi-duals } \\
\text { in the CP, } \\
\text { pc. }\end{array}$} & \multirow{2}{*}{$\begin{array}{l}\text { Density of } \\
\text { individuals of } \\
\text { all age States } \\
\text { on the area } \\
\left(1 \times 1 \mathrm{~m}^{2}\right) \text { pc. }\end{array}$} & \multirow{2}{*}{$I \mathrm{v}$} & \multirow{2}{*}{ Ip.o } \\
\hline & $j$ & im & $v$ & $g$ & & & & & & \\
\hline 2007 & 0 & 17.1 & 80.0 & 2.8 & 0.96 & 34 & 25 & 35 & 0.9 & 0.1 \\
\hline 2009 & 0 & 0 & 89.4 & 10.5 & 0.89 & 34 & 34 & 38 & 0.9 & 0.1 \\
\hline 2010 & 0 & 14.2 & 75.0 & 10.7 & 0.97 & 25 & 33 & 28 & 0.9 & 0.1 \\
\hline 2011 & 0 & 0 & 50.0 & 50.0 & 1.00 & 10 & 57 & 20 & 0.5 & 0.5 \\
\hline 2012 & 10.2 & 0 & 87.5 & 2.2 & 1.00 & 86 & 32 & 88 & 0.9 & 0.1 \\
\hline 2013 & 0 & 0 & 58.3 & 41.6 & 1.00 & 7 & 35 & 12 & 0.6 & 0.4 \\
\hline 2014 & 6.6 & 57.7 & 24.4 & 11.1 & 1.02 & 40 & 40 & 45 & 0.8 & 0.2 \\
\hline 2015 & 8.3 & 6.9 & 61.6 & 23.6 & 1.03 & 55 & 361 & 72 & 0.7 & 0.3 \\
\hline 2016 & 16.3 & 29.5 & 44.2 & 9.8 & 1.00 & 55 & 102 & 61 & 0.9 & 0.1 \\
\hline 2017 & 0 & 0 & 83.3 & 16.6 & 1.10 & 80 & 120 & 96 & 0.8 & 0.2 \\
\hline 2018 & 0 & 26.0 & 50.0 & 23.5 & 1.01 & 26 & 86 & 34 & 0.7 & 0.3 \\
\hline
\end{tabular}

immature, virgininal and generative states.

Assessment of the vitality of the CP T. riparia by the size spectrum of individuals (IVC) shows, that the most favorable years for plant growth were 2012, 2014-2018 (Table 2). In the same years the CP recorded high demographic indicators: number and density of individuals, the full age composition. The vitality type of coenopopulation in 2014-2018 is thriving (IQ is greater than one) (Table 3). The unfavorable conditions for the growth of T. riparia plants formed in dry (2007 and 2010) and cold, with low temperatures and the presence of frosts in the phase of the beginning of the growing season (2009). The vitality type of CP in 2007 and 2010 is depressive (Table 3). During these years, decreased $\mathrm{CP}$ vitality was also accompanied by relatively low va- lues of the number and density of individuals.

The variability of morphological features of vegetative and reproductive organs in the years of the study is presented in table 4 . The size indicators of individual characteristics changed 1.4-3.0 times in the years of the study. Relatively low values of morphological indicators were observed in 2007-2010, and relatively high values were observed in 2012-2018. The variability of the studied morphological features is characterized by a low, medium and high degree of variability. The shoot height attribute is characterized only by an average level of variability. The length and width of the first and second leaves are characterized by an average and high degree of variability. The length of the outer and inner perianth lobes in the years of

Table 3. The vitality type of coenopopulation of Tulipa riparia (2007-2018).

\begin{tabular}{cccccc}
\hline \hline Year & \multicolumn{3}{c}{$\begin{array}{c}\text { Proportion of generative } \\
\text { individuals by vitality } \\
\text { classes, \% }\end{array}$} & $I_{\mathrm{Q}}$ & $\begin{array}{c}\text { Vitality type of } \\
\text { coenopopulation }\end{array}$ \\
\cline { 2 - 4 } & $a$ & 6 & $c$ & & \\
\hline 2007 & 45.8 & 12.5 & 41.6 & 0.70 & depressive \\
2009 & 23.3 & 43.3 & 33.3 & 1.00 & equilibrium \\
2010 & 20.6 & 41.3 & 37.9 & 0.81 & depressive \\
2011 & 10.0 & 46.6 & 46.6 & 0.60 & depressive \\
2012 & 10.0 & 16.6 & 73.3 & 0.18 & depressive \\
2013 & 6.6 & 40.0 & 53.3 & 0.43 & depressive \\
2014 & 23.3 & 46.6 & 30.0 & 1.16 & thriving \\
2015 & 30.0 & 40.0 & 30.0 & 1.16 & thriving \\
2016 & 30.0 & 36.6 & 33.3 & 1.00 & equilibrium \\
2017 & 25.0 & 43.0 & 32.0 & 1.06 & thriving \\
2018 & 12.0 & 56.0 & 32.0 & 1.06 & thriving \\
\hline
\end{tabular}


research is characterized by a low and medium degree of variability. The width of the outer and inner perianth lobes are characterized by low, medium and high levels of variability.

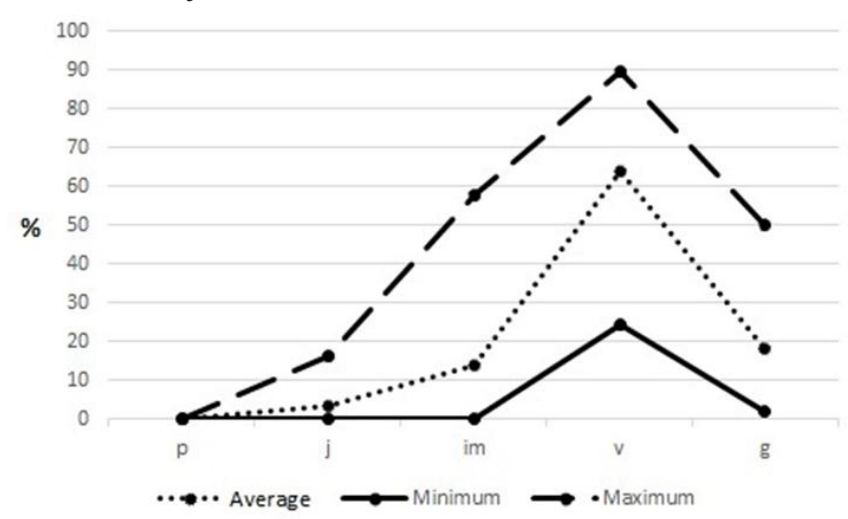

Figure 4. Averaged ontogenetic spectrum of Tulipa riparia cenopopulations on the territory of the South Ural state nature reserve (for the seasons 2007, 2009-2018).

Ontogenetic strategy. T. riparia stress-protective (Fig. $5)$. With an increase that affects the growth processes of stress, the weakening first occurs, and then the coordination of plant development is strengthened (alternating the stress and protective components in the life strategy). This type of ontogenetic strategy typical for stress-tolerance [Ishbirdin, Ishmuratova, 2004b] anthropotolerance species able to dwell in the secondary phytocenoses [Suyundukov, 2014].

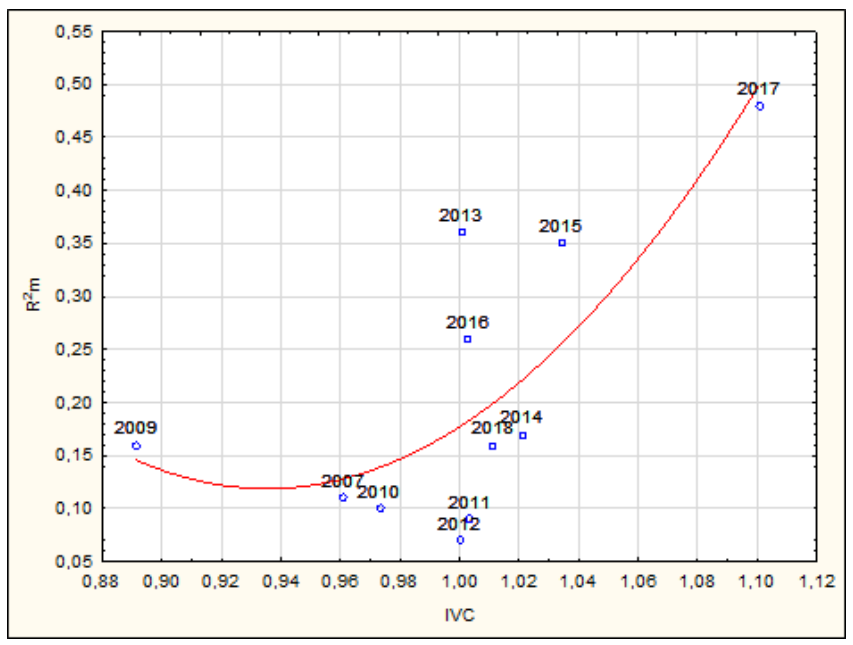

$\leftarrow$ the deterioration of growth conditions

Figure 5. Trend of ontogenetic strategy of Tulipa riparia on the territory of the South Ural reserve.

Note: on the abscissus axis - the coenopopulation vitality index (IVC), on the ordinate axis - morphological integrity (coefficient of feature determination, $\mathrm{R}^{2} \mathrm{~m}$ ).
Average coefficient of determination for all pairs of morphological structure features $\left(\mathrm{R}^{2} \mathrm{~m}\right)$ varies from 0.07 to 0.48 . The maximum value was observed in the optimal year for the CP in 2017, when the population and individual indicators coincided (Table 2, 3, Fig. 5) optimums. The most unfavorable years were 2007 , 2010-2012, which recorded low indicators of the coefficient of determination $\left(R^{2} m=0.07-0.11\right)$ (Fig. 3) and the vitality of individuals $(I V C=0.96-1.00)$ (Table 2).

Resistance of the species to anthropogenic impact. The spectrum of hemerobicity of a community with Tulipa riparia in the South Ural reserve is shown in figure 6.

The community with $T$. riparia is dominated by species with an oligo-mesohemerobic component in the individual spectrum of hemerobicity - from 34.0 to 42.6 (Fig. 6). Share anthropotolerance types (with bcp component in the spectrum gemerobnosti) is $19.1 \%$. In terms of apophytism, $T$. riparia belongs to the group of relatively stable species (Ap - 23.4). Based on the results of our research, we found that $T$. riparia is a species that is resistant to moderate anthropogenic impact. In the areas where the species grows, in the last 6 years (since 2013), there has been an annual, moderate anthropogenic load in the form of haymaking. This had a positive effect on the vitality of the species and the age range of the CP (Table 2). In the absence of moderate anthropogenic impact there is a deterioration in the condition and vitality of individuals and the $\mathrm{CP}$ as a whole.

Several forms of anthropogenic impact on the ecosystems of the South Ural State Nature Reserve have been identified: haying and grazing, selective sanitary felling, trampling, sightseeing and tourist activities, the influence of roads and railways [Barlybaeva et al., 2018]. According to the Regulation on the reserve

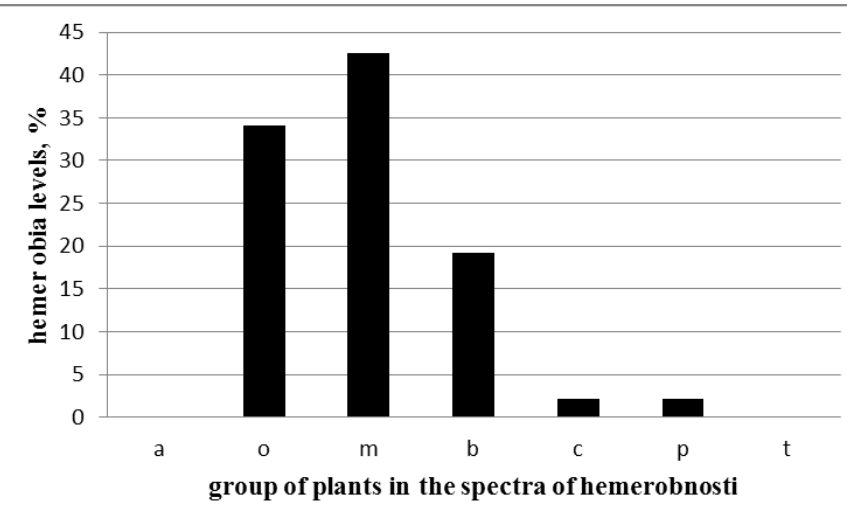

Figure 6. Spectrum of hemerobicity of communities with Tulipa riparia in the South Ural reserve. 
Table 4. Morphometric characteristics of vegetative and reproductive organs Tulipa riparia (2007-2018).

\begin{tabular}{|c|c|c|c|c|c|c|c|c|c|c|c|c|c|}
\hline \multirow{2}{*}{\multicolumn{3}{|c|}{$\begin{array}{c}\text { Years of research } \\
\text { Parameters }\end{array}$}} & 2007 & 2009 & 2010 & 2011 & 2012 & 2013 & 2014 & 2015 & 2016 & 2017 & 2018 \\
\hline & & & & & & & & & & & & & \\
\hline \multirow{3}{*}{\multicolumn{2}{|c|}{$\begin{array}{l}\text { The height of the } \\
\text { shoot, } \mathrm{cm}\end{array}$}} & M & 25.1 & 26.6 & 22.9 & 24.8 & 31. & 23.6 & 28.4 & 28.5 & 26.1 & 28.1 & 27.5 \\
\hline & & $\pm \mathrm{m}$ & 0.8 & 0.6 & 0,5 & 0.9 & 0 . & 0.8 & 0. & 0.9 & 0.8 & 1.2 & 0.8 \\
\hline & & CV, $\%$ & 15.7 & 12.9 & 11,6 & 19.9 & 13.6 & 19.8 & 18.5 & 18.0 & 17.8 & 18.7 & 14.6 \\
\hline \multirow{6}{*}{$\begin{array}{l}\text { The } \\
\text { first } \\
\text { sheet }\end{array}$} & \multirow{3}{*}{$\begin{array}{l}\text { length, } \\
\mathrm{cm}\end{array}$} & M & 12.3 & 10.2 & 9.8 & 10.4 & 13.1 & 12.3 & 15.5 & 13.8 & 13.3 & 13.3 & 14.5 \\
\hline & & $\pm \mathrm{m}$ & 0.9 & 0.4 & 0.2 & 0.5 & 0.5 & 0.5 & 0.6 & 0.6 & 0.5 & 0.7 & 0.3 \\
\hline & & $\mathrm{CV}, \%$ & 36.7 & 21.6 & 16.0 & 26.4 & 20.9 & 22.4 & 23.5 & 25.2 & 21.4 & 24.9 & 12.7 \\
\hline & \multirow{3}{*}{$\begin{array}{l}\text { width, } \\
\mathrm{cm}\end{array}$} & M & 1.6 & 1.0 & 1.3 & 1.3 & 1.3 & 1.7 & 1.9 & 1.7 & 1.8 & 1.8 & 1.4 \\
\hline & & $\pm \mathrm{m}$ & 0.05 & 0.04 & 0.04 & 0.04 & 0.05 & 0.05 & 0.05 & 0.04 & 0.1 & 0.1 & 0.03 \\
\hline & & $\mathrm{CV}, \%$ & 15.3 & 22.3 & 16.1 & 18.6 & 22.2 & 16.8 & 15.7 & 12.4 & 32.4 & 13.1 & 11.7 \\
\hline \multirow{6}{*}{$\begin{array}{l}\text { Second } \\
\text { sheet }\end{array}$} & \multirow{3}{*}{$\begin{array}{l}\text { length, } \\
\mathrm{cm}\end{array}$} & M & - & - & - & $\begin{array}{ll}- \\
-\end{array}$ & - & 9.4 & 12.5 & 11.0 & 9.7 & 10.9 & 11.1 \\
\hline & & $\pm \mathrm{m}$ & - & - & . & - & - & 0.35 & 0.57 & 0.49 & 0.46 & 0.6 & 0.2 \\
\hline & & CV,\% & - & - & - & - & - & 20.5 & 25.0 & 24.1 & 26.0 & 23.8 & 10.7 \\
\hline & \multirow{3}{*}{$\begin{array}{l}\text { width, } \\
\mathrm{cm}\end{array}$} & M & - & - & - & - & - & 1.2 & 1.2 & 1.1 & 1.0 & 1.2 & 1.0 \\
\hline & & $\pm \mathrm{m}$ & - & - & - & - & - & 0.05 & 0.05 & 0.04 & 0.03 & 0 . & 0.02 \\
\hline & & $\mathrm{CV}, \%$ & - & - & - & - & - & 22.9 & 20.3 & 17.3 & 16.3 & 20.2 & 10.1 \\
\hline \multirow{6}{*}{$\begin{array}{l}\text { Outer } \\
\text { lobe of } \\
\text { the } \\
\text { perianth }\end{array}$} & \multirow{3}{*}{$\begin{array}{l}\text { length, } \\
\mathrm{cm}\end{array}$} & $\mathrm{M}$ & 3.2 & 3.2 & 3.2 & 3.3 & 3. & 3. & 3. & 3. & 3. & 3.9 & 3.5 \\
\hline & & $\pm \mathrm{m}$ & 0.07 & 0.07 & 0.07 & 0 . & 0. & 0.08 & 0.09 & 0.05 & 0.06 & 0. & 0.04 \\
\hline & & $\mathrm{CV}, \%$ & 16.5 & 13.8 & 11.0 & 16.0 & 15. & 11.4 & 15.7 & 7.6 & 9.4 & 10.5 & 6.2 \\
\hline & \multirow{3}{*}{$\begin{array}{l}\text { width, } \\
\mathrm{cm}\end{array}$} & $\mathrm{M}$ & 1.4 & 1.4 & 2.2 & 2.2 & 1.5 & 1.4 & 1.0 & 1. & 1.2 & 2.0 & 1.2 \\
\hline & & $\pm \mathrm{m}$ & 0.05 & 0.04 & 0.09 & 0.09 & 0.1 & 0.06 & 0.05 & 0.05 & 0.04 & 0.1 & 0.02 \\
\hline & & CV, $\%$ & 10.0 & 11.1 & 21.0 & 22.5 & 51.4 & 23.7 & 27.7 & 19.2 & 15.9 & 13.5 & 8.4 \\
\hline \multirow{6}{*}{$\begin{array}{l}\text { Inner } \\
\text { lobe of } \\
\text { the } \\
\text { perianth }\end{array}$} & \multirow{3}{*}{$\begin{array}{c}\text { length, } \\
\mathrm{cm}\end{array}$} & M & - & - & - & - & - & 3.6 & 3.4 & 3.3 & 3.7 & 3.8 & 3.5 \\
\hline & & $\pm \mathrm{m}$ & - & $\begin{array}{ll}- & \text { r }\end{array}$ & - & - & 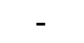 & 0.07 & 0.05 & 0.04 & 0.07 & 0.1 & 0.06 \\
\hline & & CV,\% & - & - & - & - & - & 10.0 & 7.5 & 6.3 & 9.7 & 12.1 & 8.6 \\
\hline & \multirow{3}{*}{$\begin{array}{l}\text { width, } \\
\mathrm{cm}\end{array}$} & M & - & - & - & - & - & 1.5 & 1.5 & 1.0 & 2.0 & 1.6 & $1.5 \pm$ \\
\hline & & $\pm \mathrm{m}$ & - & - & - & - & - & 0.07 & 0.06 & 0.03 & 0.04 & 0.06 & 0.06 \\
\hline & & $\mathrm{CV}, \%$ & - & - & - & - & - & 24.0 & 21.0 & 12.9 & 10.3 & 13.8 & 19.1 \\
\hline
\end{tabular}

[Regulation ..., 2009] on its territory, near settlements in limited areas, local residents are allowed haying and moderate grazing.

The T. riparia $\mathrm{CP}$ studied by us grows near the village and experiences anthropogenic stress. From 2007 to 2012 irregular haying was carried out in the places of growth. From long-term observations, it was revealed [Barlybaeva et al., 2018] that in the absence of regular moderate haying, meadows are overgrown with tall grasses (for example, Veratrum lobelianum Bernh.) and the projective cover of the grass stand increases. This leads to a decrease in the demographic indicators and vitality of $T$. riparia at the organismic and population levels (Tables 2, 3, Fig. 3). Plants with low vitality predominated in the CP (class c) (Table 3). Since 2013, regular, moderate anthropogenic load in the form of haying has been carried out in the species growing areas. The decrease in interspecific competitive relations against the background of mowing had a positive effect on the state of $T$. riparia $\mathrm{CP}$. The intensity of vegetative propagation increased, which was reflected in the age spectrum and number of individuals in the CP (Table
2, Fig. 3), the vitality of individuals (IVC> 1) (Table 2 ), and the flourishing vitality type of CP (Table 3 ). Plants with high and medium vitality (class $a$ and $b$ ) predominated in CP.

Tulipa riparia belongs to the group of opushechnomeadow species [Kulikov, 2005]. Previously by us shown [Barlybayeva et al., 2018], that the successful existence of grassland communities requires moderate anthropogenic impact in the form of haymaking or grazing. In the complete absence of anthropogenic load, some species, due to their low competitiveness, disappear from the composition of plant communities. To preserve populations of rare species that grow in the glade meadow coenosis on the reserve, it is recommended to regularly conduct haymaking after tying the fruit.

Based on monitoring studies using $P V A$, it was shown [Menges et al., 2006] that the conservation of populations of the rare species Dicerandera frutescens is also possible only against the background of regular anthropogenic impact in the form of periodic fires. 


\section{CONCLUSION}

Long-term monitoring of the South Ural endemic population Tulipa riparia, conducted on the territory of the South Ural State Nature Reserve, made it possible to assess the state of cenopopulation and develop measures for its protection. The population is characterized by fluctuations in density, total abundance, abundance of individual age groups, indicators of morphological features, vitality of individuals, and vitality type. The age spectrum of the CP is generally normal, fullfledged, only in some years there are no juvenile and immature individuals. In nature, population maintenance is only possible in an asexual (vegetative) way. Despite the decrease in the number of individuals and the incomplete age spectrum in some years, the $\mathrm{CP}$ is in a stable, satisfactory state. On the territory of the reserve, $T$. riparia displays a stress-protective ontogenetic life strategy, belongs to the group of relatively resistant species to anthropogenic impact. A moderate anthropogenic load in the form of haymaking in the areas where the species grows is recommended for a stable state of the CP.

\section{REFERENCES}

Adams V.M., Marsh D.M., Knox J.S. (2005) Importance of the seed bank for population viability and population monitoring in a threatened wetland herb. Biol. Conserv. 124: 425-436.

Barlybayeva M.Sh., Ishmuratova M.M., Gorichev Yu.P., Ishmurzina M.G. (2018) Assessment of the state of populations of rare and endangered plant species on the territory of the South Ural state nature reserve and recommendations for their conservation. Bulletin of Perm University., 1: 62-69. [Барлыбаева М.Ш., Ишмуратова М.М., Горичев Ю.П., Ишмурзина М.Г. (2018) Оценка состояния популяций редких и исчезающих видов растений на территории Южно-Уральского государственного природного заповедника и рекомендации по их сохранению. Вестник Пермского университета., 1: 62-69]

Barlybayeva M.Sh., Ishbirdin A.R., Suyundukov I.V., Ishmuratova M.M., Ilina I.V., Krivosheev M.M., Mukhametshina L.V., Nabiullin M.I., Baryshnikova N.I., Nesgovorova O.V. (2019) Floral finds in the Republic of Bashkortostan. Bulletin of Perm University., 1: 1-6. [Барлыбаева М.Ш., Ишбирдин А.Р., Суюндуков И.В., Ишмуратова М.М., Ильина И.В., Кривошеев М.М., Мухаметшина Л.В., Набиуллин М.И., Барышникова Н.И.,
Несговорова О.В. (2019) Флористические находки в Республике Башкортостан. Вестник Пермского университета., 1: 1-6]

Bochantseva Z.P. (1962) Tulips: morphology, Cytology and biology. Tashkent. Publishing house of the USSR. 408 pp. [Бочанцева, 3.П. (1962) Тюльпаны. Морфология, цитология и биология. Ташкент: Изд-во АН УзССР., 406 с.]

Brigham C., Schwartz M.W. (2003) Population viability in plants conservation, management and modeling of rare plants. N.Y.: Springer Vferlag. 362 pp.

Brook B.W., Traill L.W., Bradshaw C.J.A. (2006) Minimum viable population sizes and global extinction risk are unrelated. Ecol. Letters., 9(4): 375-332.

Coenopopulations of plants (1988) Essays on population biology. Moscow: Nauka, 184 pp. [Ценопопуляции растений: (1988) Очерки популяционной биологии. М.: Наука, 184 с.]

Danelia I.M. (1989) On the karyosystematics of some Caucasian representatives of the genus Tulipa (Liliaceae). Botanic journal, 74(2). 193200. [Данелия И.М. (1989) К кариосистематике некоторых кавказских представителей рода Tulipa (Liliaceae). Ботанический журнал, 74(2): 193-200]

Determinant of higher plants of the Bashkir ASSR (1988) Yu.E. Alekseev, K.K. Gabbasov and others. Moscow: Nauka, 316 pp. [Определитель высших растений Башкирской АССР (1988) Ю.Е. Алексеев, К.К. Габбасов и др. М.: Наука, 316 с.]

Ellenberg H. (1979) Zeigerwerte der Gefasspflanzen Mitteleuropas. 2 Aufl.: Scripta Geobotanica, (9): $100 \mathrm{pp}$.

Flora and vegetation of the South Ural state nature reserve (2008) [ed. by B. M. Mirkin]. Ufa: Gilem. 528 pp. [Флора и растительность Южно-Уральского государственного природного заповедника (2008) [под ред. Б. М. Миркина]. Уфа: Гилем, 528 с.]

Frank D., Klotz S. (1990). Biologisch-ökologische Daten zur Flora der DDR / Halle-Wittenberg: Martin-Luter-Universität. 32: 167 pp.

Garcia M.B. (2003) Demographic viability of a relict population of the critically endangered plant Bandereachouardii. Coriserv. Biol., 17(6): 16721680.

Glotov N.V. (1998) On the estimation of parameters of the age structure of plant populations. Life of populations in a heterogeneous environment. Part 1. 
Yoshkar-Ola: Periodika Mari El. 146-149. [Глотов Н.В. (1998) Об оценке параметров возрастной структуры популяций растений. Жизнь популяций в гетерогенной среде. Ч.1. - ЙошкарОла: Периодика Марий Эл, 146-149]

Grime J.P. (2001) Plant strategies, vegetation processes and ecosystem properties. Chichester: John Wiley and Sons. $176 \mathrm{pp}$.

Gross K. (2002) Efficient data collection for estimating growth rate of structured population. Ecology., 83: 1762-1767.

Ishbirdin A.R., Ishmuratova M.M. (2004A) To assess the vitality of coenopopulations of Rhodiola iremelica Boriss. by the size spectrum. Scientific notes of the NTSPA. Materials of the VI all-Russian population seminar. Nizhny Tagil, 80-85. [Ишбирдин A.P., Ишмуратова М.М. (2004A) К оценке виталитета ценопопуляций Rhodiola iremelica Boriss. по размерному спектру. Ученые записки НТГСПА. Материалы VI Всероссийского популяционного семинара. Нижний Тагил, 80-85]

Ishbirdin A.R., Ishmuratova M.M. (2004B) Adaptive morphogenesis and ecological-coenotic strategies for survival of herbaceous plants. Methods of population biology: materials VII vseros. popular. seminar's. Syktyvkar, (2): 113-120. [Ишбирдин А.Р., Ишмуратова М.М. (2004Б) Адаптивный морфогенез и эколого-ценотические стратегии выживания травянистых растений. Методы популяционной биологии: материалы VII Bсерос. популяц. семинара. Сыктывкар. (2): 113-120]

Ishbirdin A.R., Ishmuratova M.M., Zhirnova T.V. (2005) The strategy of life of the populations of Cephalanthera rubra (L.) L.C. Rich. on the territory of the Bashkir state reserve. Bulletin of the Nizhny Novgorod University, N.I. Lobachevsky. Biology Series. N. Novgorod: NNSU, 1(9): 85-98. [Ишбирдин А.Р., Ишмуратова М.М., Жирнова Т.В. (2005) Стратегия жизни ценопопуляций Cephalanthera rubra (L.) L.C. Rich. на территории Башкирского государственного заповедника. Вестник Нижегородского университета им. $Н$. И. Лобачевского. Серия Биология. Н. Новгород: ННГУ, 1(9): 85 - 98]

Ishmuratova M.M. (2006) Rodiola iremelskaya in the southern Urals. Moscow: Nauka. 252 p. [Ишмуратова М.М. (2006) Родиола иремельская на Южном Урале. М.: Наука. 252 с.]

Ishmuratova M.M., Dmitrieva A.N., Dyachenko M.A. (2019A) Reproduction in vitro of rare ornamental wild-growing sem. species. Liliaceae. Collection of articles of the IX International scientific conference "Floriculture: history, theory, practice" (September 7-13,2019, Saint Petersburg), St. Petersburg, 318-321. [Ишмуратова М.М., Дмитриева А.Н., Дьяченко М.А. (2019A) Размножение в культуре in vitro редких декоративных дикорастущих видов сем. Liliaceae. Сборник статей IX Международной научной конференции «Цветоводство: история, теория, практика» (7-13 сентября 2019 г., г. Санкт - Петербург), СПб, 318-321]

Ishmuratova M.M., Barlybayeva M.Sh., Nabiullin M.I., Ishbirdin A.R., Suyundukov I.V., Nesgovorova O.V., Kildiyarova G.N., Shamigulova A.S. (2019B) Orchids (Orchidaceae Juss.) in the southern Urals: monitoring in protected and other territories, protection issues. Bulletin of Perm University, 3: 327-345. [Ишмуратова М.М., Барлыбаева М.Ш., Набиуллин М.И., Ишбирдин А.Р., Суюндуков И.В., Несговорова О.В., Кильдиярова Г.Н., Шамигулова А.С. (2019Б) Орхидные (Orchidaceae Juss.) на Южном Урале: мониторинг на охраняемых и иных территориях, вопросы охраны. Вестник Пермского у-та, 3: 327-345]

Ishmuratova M.M., Ishbirdin A.R., Suyundukov I.V. (2003). Use of the hemerobia indicator to assess the vulnerability of certain species of orchids in the southern Urals and the stability of plant communities. Biol. Vestnik (Ukraine). 7(1-2): 33-35. [Ишмуратова М.М., Ишбирдин А.Р., Суюндуков И.В. (2003) Использование показателя гемеробии для оценки уязвимости некоторых видов орхидей Южного Урала и устойчивости растительных сообществ. Биол. вестник (Украина). 7(1-2): 33-35]

Jackowiak B. (1993) Atlas roslin naczyniowych w Poznaniu. Poznan, 409 pp.

Jacquemyn H. Brys R., Hermy M., Willems J.H. (2007) Long-term dynamics and population viability in one of the last population of the endangered Spiranthes spiralis (Orchidaceae) in the Netherlands. Biol. Conserv., 134: 14-21.

Kaigorodov A.N. (1955) Of course-the zonal classification of the climates of the globe. Moscow: Publishing house of the USSR Academy of Sciences, 119 рр. [Кайгородов А.Н. (1955) Естественнозональная классификация климатов земного шара. М.: Изд-во АН СССР, 119 с.]

Knyazev M.S., Kulikov P.V., Filippov E.G. (2001) Tulips related to Tulipa biebersteiniana (Liliaceae) in the southern Urals. Botanical magazine. 86(3): 109- 


\section{PLANT \& FUNGAL RESEARCH}

119. [Князев М.С., Куликов П.В., Филлипов Е.Г. (2001) Тюльпаны родства Tulipa biebersteiniana (Liliaceae) на Южном Урале. Ботанический журнал, 86(3): 109-119]

Kroon G.H., Jongerius M.C. (1986) Chromosome numbers of Tulipa species and the occurrence of hexaploidy. Euphytica., 35:73-76.

Kulikov P.V. (2005) Abstract of the Chelyabinsk region's flora (vascular plants). Yekaterinburg-Miass: "Geotur", 537 р. [Куликов П.В. (2005) Конспект флоры Челябинской области (сосудистые растения). Екатеринбург - Миасс: «Геотур», 537 c.]

Kutlunina N.A., Belyaev A.Yu. (2008) Genetic diversity and clonal structure in populations of two closely related Tulip species in the southern Urals. Bulletin of Orenburg state University, 81: 93-98. [Кутлунина Н.А., Беляев А.Ю. (2008) Генетическое разнообразие и клоновая структура в популяциях двух близкородственных видов тюльпана на Южном Урале. Вестник Оренбургского государственного университета, 81: 93-98]

Löfgren P., Eriksson O., Lehtila K. (2000) Population dynamics and the effect of disturbance in the monocarpic herb Carlina vulgaris (Asteraceae). Ann. Bot. Fennici., 37: 183-192.

Maschinski J., Baggs J., Quintana-Ascencio P., Menges E. (2006) Using population viability analysis to predict the effects of climate change on the extinction risk of an endangered limestone endemic shrub, Arizona clifffrose. Conserv. Biol., 20(1): 218-228.

McCarthy M.A., Possingham H.P., Day J.R., Tyre A.J. (2001) Testing the accuracy of population viability analysis. Conserv. Biol., 15(4): 1030-1038.

Menges E.S. Ascencio P.F., Weekley C.W., Caone O.G. (2006) Population viability analysis and fire return intervals for an endemic Florida scrub mint. Biol. Conserv., 127: 115-127.

Meyer S.E., Quinney D., Weaver J. (2006) A stochastic population model for Lepidium papilliferum (Brassicaceae), a rare desert ephemeral with a persistent seed bank. Amer. J. Bot., 93: 891-902.

Morris W.F., Doak D., Groom M. et al. (1999) A practical handbook for population viability analysis. The Natur. Conserv. London. 83 pp.

Mukhametshina L.V., Ishmuratova M.M., Mullabayeva E.Z. (2013) Demographic characteristics of species of the genus Tulipa L. in the southern Urals. Izvestiya Samara scientific center of the Russian Academy of Sciences, 15-3(4): 1398-1401. [Мухаметшина Л.В., Ишмуратова М.М., Муллабаева Э.3. (2013) Демографическая характеристика видов рода Tulipa L. на Южном Урале. Известия Самарского научного центра РАН., 15-3(4): 1398-1401]

Mukhametshina L.V., Barlybayeva M.Sh., Ishmuratova M.M., Mullabayeva E.Z. (2014) Assessment of the state of coenopopulations of Tulipa riparia Knjasev, Kulikov et Philippov during monitoring studies on the territory of the South Ural state priodny zapovenik. Proceedings of the South Ural state nature reserve. Ufa: Gilem, Bask. Encyclopaedia. 2: 117-131. [Мухаметшина Л.В., Барлыбаева М.Ш., Ишмураова М.М., Муллабаева Э.3. (2014) Оценка состояния ценопопуляции Tulipa riparia Knjasev, Kulikov et Philippov при мониторинговых исследованиях на территроии Южно-Уральского государственного приодного заповеника. Труды Южно-Уральского государственного природного заповедника. Уфа: Гилем, Башк. Энцикл., 2: 117131]

Mullabaeva E.Z. (2005) Features of biology, coenopopulation characteristics, tactics and strategies of survival of some rare species of the family Liliaceae and Iridaceae in the southern Urals: autoref. Diss. ... Cand. Biol. sciences. Ufa. 20 pp. [Муллабаева Э.3. (2005) Особенности биологии, ценопопуляционные характеристики, тактики и стратегии выживания некоторых редких видов семейства Liliaceae и Iridaceae на Южном Урале: Автореф. дисс. ...канд. биол. наук. Уфа, 20 с.]

Mursal N., Mehdiyeva N.P. (2018) Ontogenetic structure of coenopopulations and variability of morphoparameters of Iris reticulata M. Bieb. Plant \& Fungal Research., 1(1): 52-61.

Mursal N., Mehdiyeva N.P. (2019). Studies on the botanical and ecological aspects of a rare species Ophrys caucasica from Azerbaijan (Orchidaceae). Academia Journal of Medicinal Plants, 7(9): 206217.

Münzbergová Z. (2011) Population dynamics of diploid and hexaploid population of a perennial herb. Annals Bot., 108(2): 1259-1270.

Noon B.R., Lamberson R.H., Boyce M.S., Irwin L.L. (1999) Population viability analysis: a primer on its principal technical concepts. Ecological stewardship. Eds. Szro R.C., Johson K. et al. Oxford: Elsevier Sci., 2: 87-134.

Rabotnov T.A. (1950) Life cycle of perennial herbaceous plants in meadow cenoses. Trudy BIN an SSSR. 
Ser. 3. Geobotany, 6: 7-204. [Работнов T.А. (1950) Жизненный цикл многолетних травянистых растений в луговых ценозах. Труды БИН АН CССР. Сер. 3. Геоботаника, 6: 7-204]

Reed J.M., Akçakaya H.R., Burgman M.. et al. (2006) Critical habitat. The endangered species act at thirty: conserving biodiversity in human-dominated landscapes. Ed. Scott J.M.N.Y.: Isl. Press,. 1: 164177.

Red book of the Republic of Bashkortostan (2011) Plants and mushrooms [under the editorship of Dr. Biol. of science, Prof. B.N. Mirkina]. Ufa. Media Print. 1: 384 pp. [Красная книга Республики Башкортостан: (2011) Растения и грибы [под ред. д-ра биол. наук, проф. Б.Н. Миркина]. Уфа: Медиа Принт. 1: 384 с.]

Red book of the Chelyabinsk region (2017) Animals, plants, and fungi. Moscow. 506 pp. [Красная книга Челябинской области. (2017) Животные, растения, грибы. Москва. 506 с.]

Regulations on the Federal State Institution "South Ural State Nature Reserve" (2009) Moscow. 24 pp. [Положения о Федеральном государственном учреждении "Южно-Уральский государственный природный заповедник" (2009) Москва. 24 с.]

Rostova N.S. (2002) Korrelyatsiy: struktura i izmenchivost. Sankt-Peterburq: Izd. S.Peterburqskava Universiteta, 308 pp. [Ростова Н.С. (2002) Корреляции: Структура и изменчивость. СПб.: Изд- во СПб. ун-та. 308 с.]

Suyundukov I.V. (2014) Strategies for the life of certain types of sem. Orchidaceae (Juss.) and issues of protection of orchids in the southern Urals: autoref. dis. Dr. Biol. sciences. Ufa. 43 pp. [Суюндуков И.В. (2014) Стратегии жизни некоторых видов сем. Orchidaceae (Juss.) и вопросы охраны орхидей на Южном Урале: Автореф. дис. доктора биол. наук. - Уфа. 43 с.]

Tews J. (2004) Plant population viability analysis in conservation biology: a review. N.Y.: Elatis Modeling and Consulting Inc., 13 pp.

Vereshchak E.V., Ishmuratova M.M. (2009) Assessment of the viability of Dianthus acicularis Fisch. ex Ledeb in monitoring studies in the southern Urals. Botanical research in the Urals: materials of the region. scientific Conf. Perm. 59-62. [Верещак E.B., Ишмуратова М.M. (2009) Оценка жизненности Dianthus acicularis Fisch. ex Ledeb при мониторинговых исследованиях на Южном
Урале. Ботанические исследования на Урале: материалы регион. науч. конф. Пермь. 59-62]

WFO, 2020: http://www.worldfloraonline.org/

Zaitsev G.N. (1984) Mathematical statistics in experimental botany. Moscow: Nauka. 424 pp. [Зайцев Г.Н. (1984) Математическая статистика в экспериментальной ботанике. М.: Наука, 424 с.]

Zlobin Y.A. (1989) Prinsipi i metodi izucheniya tsenoticheskix populyatsiy rasteniy. Kazan. 146 pp. [Злобин Ю.А. (1989) Принципы и методы изучения ценотических популяций растений. Казань. 146 с.]

Zonneveld B.J.M. (2009) The systematic value of nuclear genome size for «all» species of Tulipa L. (Liliaceae). Plant Syst. Evol., 281: 217-245.

\section{Conubi Uralda Tulipa riparia Knjasev, Kulikov et Philippov populyasiyasının vəziyyətinin monitorinqi}

\section{Milyauşa Ş. Barlıbaeva}

Canubi-Ural Dövlat Tabii Qoruğu, Beloretskiy rayonu, Rivet kəndi, Markazi Malikana, 453560, Başqurdıstan Respublikası

\section{Maya M. İșmuratova}

Başkir Dövlat Universiteti, Ufa, Zaki Valido küç., 32, Başqırdıstan; Başkir Dövlat Qoruğu, Başqurdıstan

Məqalədə Cənubi Ural qoruğunda Liliaceae fəsiləsinə aid Tulipa riparia Knjasev, Kulikov et Philippov senopopulyasiyasının uzunmüddətli monitorinqinin nəticələri təqdim edilir. Göstərilir ki, senopopulyasiya üçün hava-iqlim şəraitindən asılı olaraq sıxlılğın, sayın və fərdlərin həyatilinin, yaş spektrinin, morfometrik xüsusiyyətlərin əhəmiyyətli fluktuasiyası xarakterikdir. Senopopulyasiyanın yaş spektri virginal fərdlərin üstünlüyü ilə normaldır, sağtərəflidir. Növün qoruq ərazisində stres-müdafiə ontogenetik həyat strategiyas1 aşkar edilmişdir. Apofitizm göstəricisinə görə T. riparia antropogenik təsirlərə nisbi davamlı növlər qrupuna aiddir. Növün bitmə yerində ot biçmə kimi mötədil antropogen yüklənmə populyasiyanın xarakteristikasına, fərdlərin həyatiliyinə və senopopulyasiyanın vitalitet tipinə müsbət təsir edir.

Açar sözlor: Liliaceae, populyasiya, monitorinq, qoruma, qoruq 


\section{PLANT \& FUNGAL RESEARCH}

\section{Мониторинг состояния ценопопуляции Tulipa riparia Knjasev, Kulikov et Philippov на Южном Урале}

\section{Миляуша Ш. Барлыбаева}

Южно-Уральский Государственный Природный Заповедник, Белореикий район, с. Реветь, Центральная усадьба, 453560, Республика Башкортостан

\section{Майя М. Ишмуратова}

Башкирский Государственный Университет, Уфа, Заки Валидо у. 32 Башкортостан; Башкирский Государственный Заповедник, Башкортостан

В статье приводятся итоги долгосрочного мониторинга ценопопуляции тюльпана приречного (Tulipa riparia Knjasev, Kulikov et Philippov) сем. Liliaceae, произрастающего на территории Южно-Уральского заповедника. Показано, что для ценопопуляции характерны значительные флуктуации плотности, численности и жизненности особей, возрастных спектров, морфометрических характеристик в зависимости от погодно-климатических условий. Возрастной спектр ценопопуляции нормальный, правосторонний, с преобладанием виргинильных особей. Для территории заповедника у вида выявлена стрессовозащитная онтогенетическая стратегия жизни. По показателю апофитизма $T$. riparia относится к группе относительно устойчивых к антропогенному воздействию видов. Умеренная антропогенная нагрузка в виде сенокошения в местах произрастания вида положительно воздействует на популяционные характеристики, жизненность особей и виталитетный тип ценопопуляции.

Ключевые слова: Liliaceae, популяция, мониторинг, охрана, заповедник 